\title{
Wet and Wonderful: The World's Largest Wetlands Are Conservation Priorities
}

PAUL A. KEDDY, LAUCHLAN H. FRASER, AYZIK I. SOLOMESHCH, WOLFGANG J. JUNK, DANIEL R. CAMPBELL, MARY T. K. ARROYO, AND CLEBER J. R. ALHO

\begin{abstract}
Wetlands perform many essential ecosystem services_carbon storage, flood control, maintenance of biodiversity, fish production, and aquifer recharge, among others - services that have increasingly important global consequences. Like biodiversity hotspots and frontier forests, the world's largest wetlands are now mapped and described by an international team of scientists, highlighting their conservation importance at the global scale. We explore current understanding of some ecosystem services wetlands provide. We selected four of these wetlands (the largest peatland, West Siberian Lowland; the largest floodplain, Amazon River Basin; the least-known wetland, Congo River Basin; and the most heavily developed wetland, Mississippi River Basin), and we illustrate their diversity, emphasizing values and lessons for thinking big in terms of conservation goals. Recognizing the global significance of these wetlands is an important first step toward forging global conservation solutions. Each of the world's largest wetlands requires a basinwide sustainable management strategy built on new institutional frameworks-at international, national, and regional levels - to ensure provision of their vital services.
\end{abstract}

Keywords: ecosystem function, ecosystem service, global priority, largest wetlands, wetland conservation

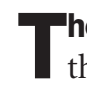
he losses of wetlands have been exceptional during the last two centuries. Estimates of wetland loss exceed $50 \%$ for the conterminous United States and for Europe (Finlayson and Davidson 1999, Dahl 2000). More extreme cases include losses of $80 \%$ of Pacific Coast estuarine wetlands in Canada; $88 \%$ of the Cauca River system in Colombia; and $90 \%$ (or more) of wetland areas in New Zealand and in the states of Ohio and California (Moser et al. 1996). The remaining wetlands are increasingly valued for their ecological services - that is, benefits wetlands provide to people (MEA 2005). In Africa, for example, where shortages of protein continue to cause malnutrition, the area of wetland in a watershed is a strong predictor of fish harvests (Welcomme 1976). Perhaps the most important, yet least appreciated, value of wetlands is their very wetness - water has been identified as one of the critical limiting resources for human civilization (Postel et al. 1996, deVilliers 2003).

As public attitudes toward wetlands have changed, there has been more legislation to protect them. The United States, for example, now has a national policy of no net loss of wetlands; projects that eliminate one area of wetland must replace it with another area of similar wetland, and the law stipulates that higher priority be given to avoidance or minimization of wetland loss (before compensation) (NRC 2001, Turner et al. 2001). Countries such as Australia and South Africa apply environmental flow assessment (EFA) in any development project that affects rivers. EFA is defined as "how much of the original flow regime of a river should continue to flow down it and onto its floodplain in order to maintain specified, valued features of the ecosystem" (Tharme 2003). At the international level, the Ramsar Convention on Wetlands was established to protect wetlands (Frazier 1999). Currently, 155 contracting parties (countries) have signed the convention (www.ramsar.org), covering 1674 wetland sites totaling 150 million hectares (ha). In a relatively short period of human history, scientists and conservationists have successfully changed public opinion about wetlands. Once viewed as waste areas in need of "reclamation," they are increasingly valued and protected. This change in attitude over about two generations (ca. 40 years) is a global environmental success story.

Although databases of global wetland extent and characteristics have been tabulated by biogeochemists and remotesensing experts (e.g., Spiers 2001, Mitra et al. 2005), 
conservation activity in wetlands has lacked global priorities. Where should these priorities lie? We have maps showing the world's last frontier forests (Bryant et al. 1997), the world's ecoregions (Olson et al. 2001), and world biodiversity hotspots (Myers et al. 2000), but nothing similar for wetlands. As a consequence, there is significant risk that conservation activities will be carried out in the absence of ecological priorities. As but two examples, we note the concentration of Ramsar sites in Western Europe, particularly in Great Britain (Frazier 1999, MEA 2005), and the enormous number of publications on wetlands in the Netherlands contrasted with the dearth of recent work in the Congo River Basin. Lacking objective criteria, people tend to focus on what is in their backyards.

Over the past decade, we have worked with an international team of scholars to refocus the study of wetland ecology at the global scale, a first step being to describe the world's largest wetlands. A provisional list of these wetlands was compiled in the late 1990s and published in studies by Keddy (2000) and Fraser and Keddy (2005). Then, as now, we have accepted credibly published estimates of area, recognizing that such published estimates include different kinds of assumptions, techniques, and accuracy. Although there is room for debate about what kinds of plant communities belong in the category "wetland," we suspect that problems of definition are not a serious source of error, as wetland ecologists generally agree about what constitutes wetlands (Keddy 2000, Mitsch and Gosselink 2000). One source of uncertainty is estimates of area in wetlands with networks of seasonally flooded channels (such as the Amazon), or with sets of isolated basins (such as the North American prairie potholes). A further difficulty might arise from inconsistencies in the inclusion of areas with heavy human disturbance, such as the vast areas of wetland that were altered by levee construction and converted to agriculture in the Mississippi River Basin. Some authors may have left out heavily developed or urbanized areas along the borders of wetlands. Given the scale at which researchers were operating and other possible sources of error, we suspect that such differences in opinion and methodology would not have a major impact on the ranking results. Such issues might, however, become more of a concern at small scales (that is, wetlands under 50,000 square kilometers $\left[\mathrm{km}^{2}\right]$ ), where there are many more candidates to evaluate and relatively smaller differences among them. Like all scientific estimates, our estimates of area are certainly provisional and subject to eventual revision with better methodology.

\section{Services provided by wetlands}

The many benefits to human society that wetlands provide can be placed in four main categories: provisioning, regulating, supporting, and cultural services (services are equivalent to products, functions, and attributes, as recognized by the Millennium Ecosystem Assessment [MEA 2005]). One estimate for the value of these services is $\$ 14,785$ per ha per year for interior wetlands and $\$ 22,832$ per ha per year for coastal esturaries (Costanza et al. 1997). For example:
- Wetlands are critical components of watersheds and are essential for ecosystem sustainability. Destruction or degradation of headwater wetlands can have extensive effects on the health and productivity of all the streams, lakes, and rivers downstream (Meyer et al. 2003).

- Wetlands recharge water supplies. In northern glaciated prairies, one hectare of forested wetland overlying permeable soil may release up to 939,500 liters of water per day into groundwater (Hayashi et al. 2003). Wetlands also have the potential to store snowmelt runoff. Destruction of wetlands can reduce groundwater levels. Ewel (1990) has estimated that if $80 \%$ of a Florida cypress swamp were drained, the associated groundwater would be reduced by approximately $45 \%$.

- Wetlands stabilize shorelines, retaining sediment and reducing erosion.

- Wetlands act as natural filters that can improve water quality (Kadlec and Knight 1996) and reduce the threat of eutrophication (Mitsch et al. 2001), as well as store large amounts of sediment (Day et al. 2007).

- Wetlands can be carbon sinks, with important implications for global climate change. For example, global peatlands can store between 400 and 500 gigatons (Gt) of carbon (Roulet 2000).

- Wetlands help control floods through the storage of large amounts of water. Wetland restoration in the upper Mississippi River Basin would most likely have stored enough water to accommodate the 1993 floods in the US Midwest (Hey and Philippi 1995).

- Wetlands maintain biodiversity by providing habitat for many animal and plant species The Amazon supports more than 2000 fish species, and even African savanna mammals depend upon wetlands during dry periods (Keddy 2000).

- Wetlands produce consumer products such as fish and shellfish, cranberries, blueberries, rice, and timber, as well as medicines derived from wetland plants. Shrimp production in the Gulf of Mexico, for example, can be related to the area of salt marshes (Turner 1977).

- Wetlands are used for a broad range of consumptive and nonconsumptive recreational activities. In Canada alone, the economic value of nature-related activities in 1996 was estimated to contribute $\$ 11$ billion to the gross domestic product (Environment Canada 2000), although the proportion of this attributable to wetlands alone is not known.

The breadth of services provided by wetlands is illustrated in table 1. We will discuss three services in more depth: carbon cycling and climate regulation, freshwater supply, and biodiversity maintenance.

\section{An issue of scale}

Why does size matter? E. F. Schumacher titled his now classic book of 1973 Small Is Beautiful: A Study of Economics as if People Mattered. In the realm of ecology, we beg to 


\begin{tabular}{|c|c|}
\hline Service type & Services \\
\hline Regulation & $\begin{array}{l}\text { Protection against harmful cosmic influences } \\
\text { Regulation of the local and global energy balance } \\
\text { Regulation of the chemical composition of the atmosphere } \\
\text { Regulation of the chemical composition of the oceans } \\
\text { Regulation of the local and global climate (including the hydrological } \\
\text { cycle) } \\
\text { Regulation of runoff and flood prevention (watershed protection) } \\
\text { Water-catchment and groundwater recharge } \\
\text { Prevention of soil erosion and sediment control } \\
\text { Formation of topsoil and maintenance of soil fertility } \\
\text { Fixation of solar energy and biomass production } \\
\text { Storage and recycling of organic matter } \\
\text { Storage and recycling of nutrients } \\
\text { Storage and recycling of human waste } \\
\text { Regulation of biological control mechanisms } \\
\text { Maintenance of migration and nursery habitats } \\
\text { Maintenance of biological (and genetic) diversity }\end{array}$ \\
\hline Carrier & $\begin{array}{l}\text { Human habitation and (indigenous) settlements } \\
\text { Cultivation (crop growing, animal husbandry, aquaculture) } \\
\text { Energy conversion } \\
\text { Recreation and tourism } \\
\text { Nature protection }\end{array}$ \\
\hline Production & $\begin{array}{l}\text { Oxygen } \\
\text { Water (for drinking, irrigation, industry, etc.) } \\
\text { Food and nutritious drinks } \\
\text { Genetic resources } \\
\text { Medicinal resources } \\
\text { Raw materials for clothing and household fabrics } \\
\text { Raw materials for building, construction, and industrial use } \\
\text { Biochemicals (other than fuel and medicines) } \\
\text { Fuel and energy } \\
\text { Fodder and fertilizer } \\
\text { Ornamental resources }\end{array}$ \\
\hline Information & $\begin{array}{l}\text { Aesthetic information } \\
\text { Spiritual and religious information } \\
\text { Historic information (heritage value) } \\
\text { Cultural and artistic inspiration } \\
\text { Scientific and educational information }\end{array}$ \\
\hline
\end{tabular}

differ with Schumacher; here, large is beautiful. Most wetland services (table 1) increase with area. Some services, such as fish production (Welcomme 1976) or stream flow maintenance (Tiner 2005), may be directly proportional to area. Others, such as carbon sequestration, will be a function of area times depth (Roulet 2000). A number of services, such as biodiversity support, have more complex relationships-species richness generally increases with area as $c(\text { area })^{z}$, where $z$ is an exponent usually less than 3.0 and $c$ is a constant (figure 1).

Larger wetlands tend to have more interior than edge habitat. Once the area effect is removed, recent work in temperate zone wetlands indicates, the most important factors controlling plant diversity are amount of adjoining forest (positively correlated with biotic diversity) and length of nearby road networks (negatively correlated with biotic diversity) (Houlahan et al.
2006). Large areas of interior habitat may be particularly important to large carnivores, a group considered to be significantly at risk from landscape fragmentation. Floodplains provide a haven for these species even in the heartland of heavily developed North America (figure 2). We are not suggesting, of course, that wetlands at the other extreme are ecologically insignificant. Isolated wetlands near urban centers, for example, may be locally important for many services, including acting as a reservoir of noteworthy species.

Whatever the research and conservation goal, large wetland areas (figure 3, table 2) demand attention.

\section{Large wetlands: Carbon cycling and climate regulation}

Peatlands, by definition, are composed of partially decayed accumulations of plants, and other wetlands often have organic soils. Global estimates for stored carbon in wetlands (between 202 and $535 \mathrm{Gt}$ ) are lower than the estimated carbon pool in the atmosphere $(720 \mathrm{Gt})$, but in the same order of magnitude as the carbon fixed as oil (230 Gt) or natural gas (140 Gt; Mitra et al. 2005).

The rate of removal of carbon from the atmosphere depends upon both rates of primary production and rates of storage as peat. These vary greatly among wetland types. Khramov and Valutsky (1977) studied aboveground biomass and net primary production of major vegetation types in the Vasyugan bog, of the south taiga zone of the West Siberian Lowland. They reported that total dry aboveground biomass in coniferous forests was 120 to 170 tons per ha; in forested bogs, 19 to 58 tons per ha; and in open raised-string sphagnum bogs, 3.4 tons per ha. The annual aboveground net primary production in forested bogs varied from 2 to 4 tons per ha per year, and in open raised string bogs, it averaged 2.6 tons per ha per year. In forests and

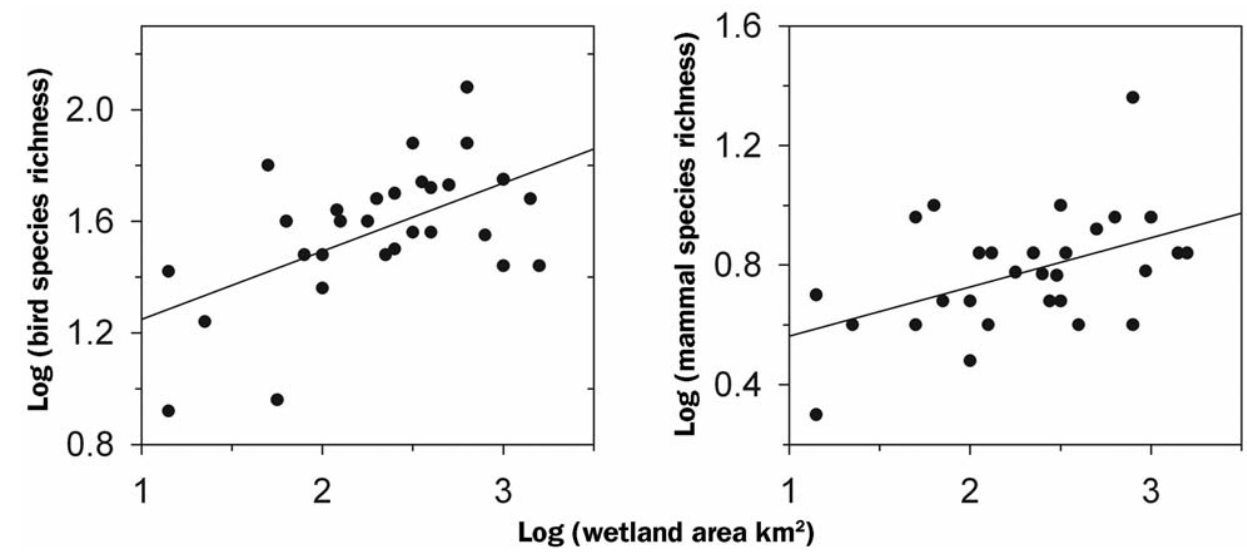

Figure 1. The number of species in a wetland increases with area (square kilometers). Source: Findlay and Houlahan (1997). 

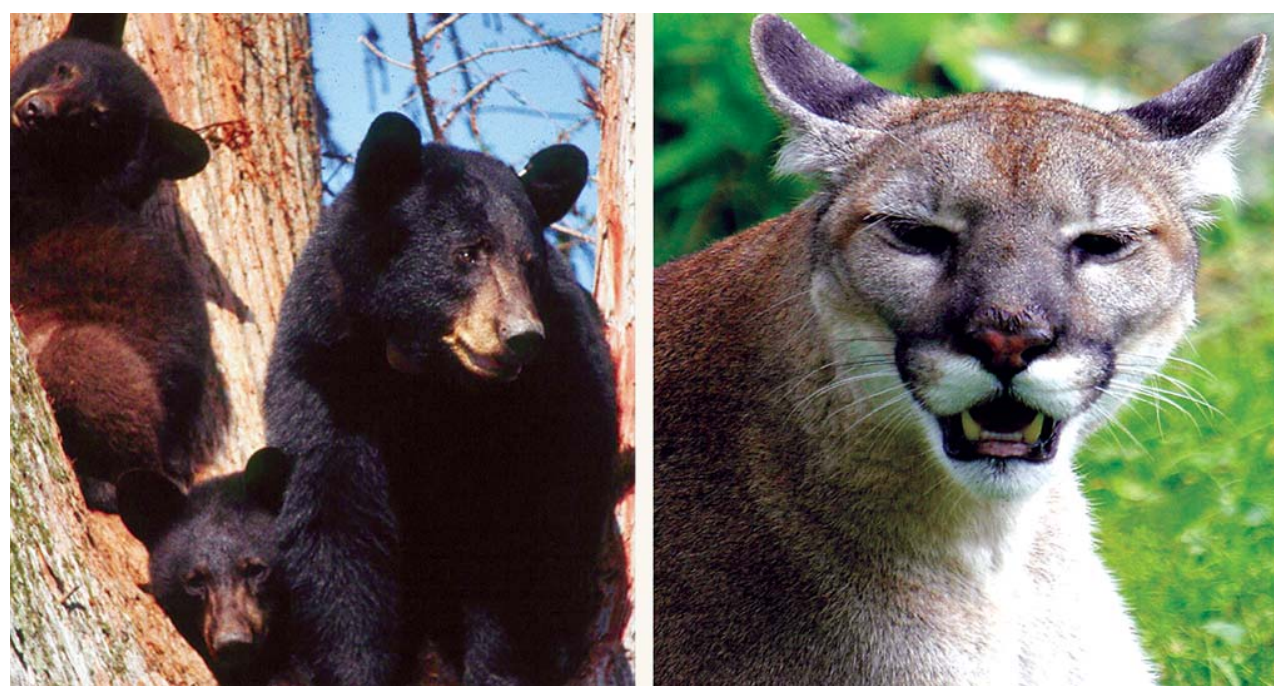

Figure 2. Large animals need large areas of habitat. The Louisiana black bear and Florida panther are two of the significant species associated with wetlands of the Mississippi River basin. The Louisiana black bear (courtesy of the US Fish and Wildlife Service) is threatened in the United States. The Florida panther (courtesy of Rodney Cammauf, US National Park Service) no longer occurs in the region and is on the IUCN list of critically endangered species. the West Siberian Lowland to be $592,440 \mathrm{~km}^{2}$, with a total carbon pool of 70.2 billion tons. Inclusion of thin peats $(<50$ centimeters) roughly doubles this peatland area. Another study based on expert assessments estimated the West Siberian Lowland peatland area at 787,000 $\mathrm{km}^{2}$, the carbon pool at 76.4 billion tons, and the average annual carbon accumulation rate at 22.8 million tons per ha per year (Solomeshch 2005). To put this in context, the boreal and subarctic peatlands of Eurasia and North America (3.46 million $\mathrm{km}^{2}$ ) store 270 billion to 455 billion tons of carbon as peat, with an average carbon accumulation rate of 66 million to 96 million tons per ha per year (Gorham 1991, Turunen et al. 2002). Tak- forested bogs, $70 \%$ to $85 \%$ of the biomass is concentrated in the tree layer, whereas in open bogs, $60 \%$ to $75 \%$ accumulates in the moss layer.

Despite their relatively low productivity, bogs have the largest peat deposits and highest long-term carbon accumulation rates. Estimates of carbon storage vary considerably, depending on the methods used to calculate them (Kremenetski et al. 2003, Mitra et al. 2005). A geographic information system-based inventory of archival and new data of peatland distribution and peat quality estimated the peatland extent of

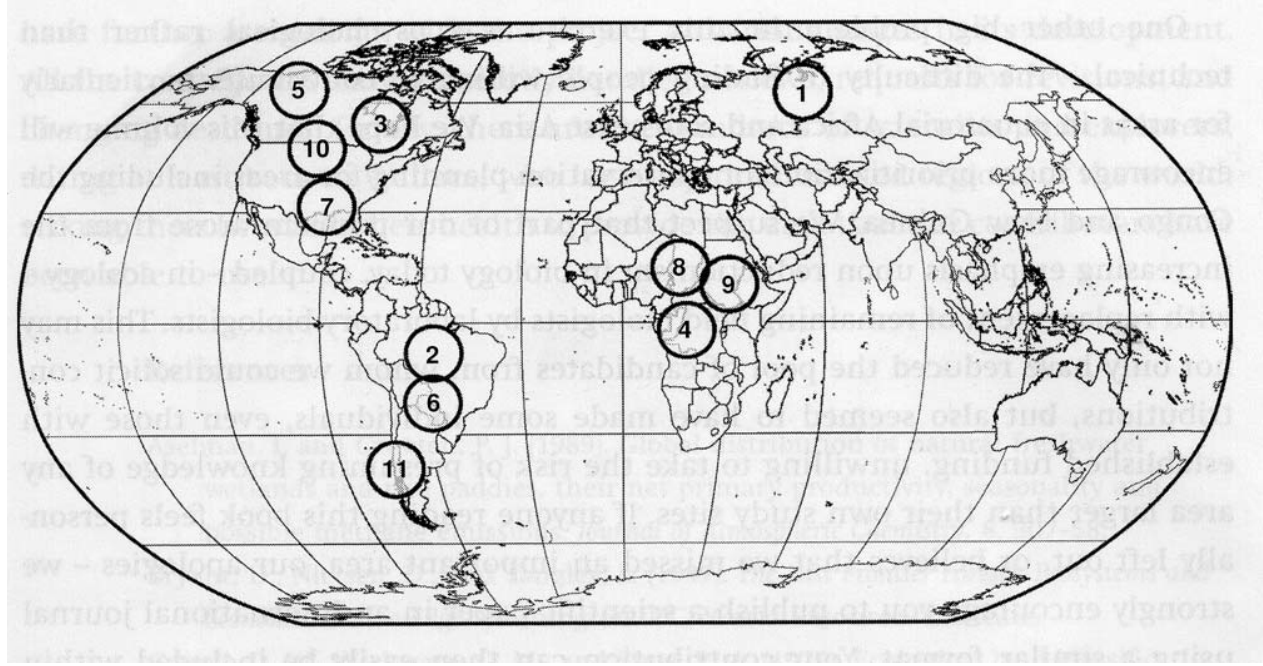

Figure 3. The world's largest wetlands ranked by area (from Keddy and Fraser 2005): 1 = West Siberian Lowland, 2 = Amazon River Basin, 3 = Hudson Bay Lowland, $4=$ Congo River Basin, 5 = Mackenzie River Basin, $6=$ Pantanal, $7=$ Mississippi River Basin, $8=$ Lake Chad Basin, 9 = River Nile Basin, 10 = Prairie Potholes, $11=$ Magellanic Moorland Reprinted with permission from Cambridge University Press. ing into account the range of these estimates, the West Siberian peatlands most likely represent $23 \%$ of the area, $17 \%$ to $28 \%$ of the carbon storage, and $24 \%$ to $35 \%$ of the annual carbon accumulation of the world's northern peatlands. These figures do not include the organic carbon storage in West Siberian forests.

The upper reaches of the Amazon floodplain, in contrast, appear to contribute little to the long-term storage of organic carbon, but mean primary production in marshes reaches about 50 tons per ha per year. Some grasses may reach up to 100 tons per ha per year, but the decomposition rate is also very high (Junk and Piedade 2005). Sequestration of organic carbon may be significant in the delta where sediments accumulate and are rapidly buried by newly arrived material. A conservative estimate yields 36.1 million tons per year of particulate carbon transported by the Amazon River to the Atlantic Ocean (Richey et al. 1990). If, however, sediment suspended through the entire water column and carbon particles larger than 1 millimeter in size are added, the effective total could exceed 100 million tons per year, or one-tenth of the world's organic carbon efflux in large rivers. The proportion of this efflux that remains stored in sediments is unknown. 


\begin{tabular}{|c|c|c|c|c|}
\hline Rank & Continent & Wetland & Description & Area $\left(\mathrm{km}^{2}\right)$ \\
\hline 1 & Eurasia & West Siberian Lowland & Bogs, mires, fens & $2,745,000$ \\
\hline 2 & South America & Amazon River Basin & Savanna and forested floodplain & $1,738,000$ \\
\hline 3 & North America & Hudson Bay Lowland & Bogs, fens, swamps, marshes & 374,000 \\
\hline 4 & Africa & Congo River Basin & Swamps, riverine forest, wet prairie & 189,000 \\
\hline 5 & North America & Mackenzie River Basin & Bogs, fens, swamps, marshes & 166,000 \\
\hline 6 & South America & Pantanal & Savannas, grasslands, riverine forest & 160,000 \\
\hline 7 & North America & Mississippi River Basin & Bottomland hardwood forest, swamps, marshes & 108,000 \\
\hline 8 & Africa & Lake Chad Basin & Grass and shrub savanna, shrub steppe, marshes & 106,000 \\
\hline 9 & Africa & River Nile Basin & Swamps, marshes & 92,000 \\
\hline 10 & North America & Prairie Potholes & Marshes, meadows & 63,000 \\
\hline 11 & South America & Magellanic Moorland & Peatlands & 44,000 \\
\hline
\end{tabular}

There are two other important considerations for carbon storage and global climate. First, carbon storage is very dependent on water level. When peatlands are drained, rates of decomposition increase; if drained and allowed to burn, carbon is rapidly returned to the atmosphere. Second, methane is a more potent greenhouse gas than carbon dioxide, by a factor of 21 (Mitra et al.2005), and wetlands release methane into the atmosphere. The effects of methane production seem nearly to balance the cooling effects of carbon storage, although there are still many uncertainties in such calculations (Mitra et al. 2005). As but one example of biological uncertainty, the stems of wetland plants provide an important pathway for methane transport from soil to atmosphere, and are included in global methane models, yet actual estimates of plant-mediated transport are "sparse" (Walter et al. 2001).

\section{Large wetlands: Freshwater supply}

Freshwater is predicted to be one of the most important resources of this century. Humans used more than half (54\%) of the accessible freshwater in 1990 (Postel et al. 1996). Not only is accessible freshwater limited, but also the suitability of freshwater for human consumption is declining. It has been estimated that 1.1 billion people do not have adequate access to clean drinking water (MEA 2005).

Large wetlands are a highly valuable source for freshwater. For example, the Amazon River dwarfs all other sources of flowing freshwater: its average discharge of 180,000 cubic meters per second is more than four times the flow of the $\mathrm{Ob}$ River that drains the West Siberian Lowland. The other large wetlands in table 2 also support significant rivers.

Wetlands can also improve the quality of water by trapping sediment and by removing nutrients from moving water (Kadlec and Knight 1996, Mitsch et al. 2001), and there are now thousands of constructed treatment wetlands that use this process for water purification.

Human civilizations have been associated with wetlands for millennia, partly because of the steady supply of freshwater, partly because of the rich alluvial soils for agriculture, and partly because of high rates of animal food production. This often means that high human population levels occur in areas that are at high risk for flooding. Most of Bangladesh, for example, is one large delta built by the Ganges and Brahmaputra rivers. The population of 150 million people lives in an area about the size of Louisiana (Bangladesh, 133,910 $\mathrm{km}^{2}$; Louisiana, 134,382 $\mathrm{km}^{2}$ ), making Bangladesh one of the most densely populated countries in the world. Extreme floods occurred in 1987, 1988, and 1989, and it is possible that flooding could engulf as much as $70 \%$ of the country (Mirza 2003). By storing water and releasing it slowly, wetlands can reduce flood levels and contribute to the well-being of populations in floodplains. Hence, wetland restoration upstream has been offered as a tool for flood reduction (Hey and Philippi 1995). Such projects would likely have beneficial effects on water quality.

Finally, freshwater flow may have implications for climate. Freshwater contributes significantly to stratification of the ocean near the surface and supports sea-ice formation, which can influence the regulation of Arctic climate and the global freshwater cycle. Three of the largest wetlands - the West Siberian Lowland, the Hudson Bay Lowland, and the Mackenzie River Basin-drain northward. These rivers, and hence the wetlands that nourish them, have another impact on global climate. In the spring, melting occurs in the headwater regions of these rivers before it does at the mouths. Large volumes of freshwater flowing northward therefore advance spring warming in the river valleys, and then break pack ice in the estuaries, changing local climates and providing open water for marine and estuarine species (Czaya 1983).

\section{Large wetlands: Biodiversity maintenance}

Maintenance of biodiversity is a widely accepted service provided by natural ecosystems, with high biodiversity of wetlands receiving particular attention (e.g., Keddy 2000, Mitsch and Gosselink 2000, MEA 2005). However, reliable comparative data are scarce. Data on biodiversity can focus either on specific wetlands or on specific taxa. Lévêque and colleagues (2005) surveyed freshwater animal diversity using both 
published sources and museum collections, concluding that the current order of magnitude is some 100,000 animal species that require freshwater. Of these, 50,000 are insects; there are 20,000 vertebrate species, 10,000 crustacean species, and 5000 mollusk species. To this list of freshwater species one would need to add species using coastal wetlands for a global total.

Focusing upon specific groups of organisms (fish, birds, mammals), we further illustrate the significance of large wetlands.

Fish. The Amazon River has more species of fish (approximately 2000) than any other river in the world, with particularly large numbers of species of characoids and silunroids (Lowe-McConnell 1975). The former group includes the fruit-eating fish in the genus Colossoma that forages in forests during high-water periods. It also includes the carnivorous piranha. The latter group includes the many species of catfish that forage in deeper water. The next most important rivers for fish biodiversity are the Congo and the Mekong, the latter having the world's largest freshwater fish, the Mekong giant catfish.

Birds. Some 1800 species of birds may be wetland dependent; wading birds are an obvious group, as are ducks and kingfishers (Lévêque et al. 2005). According to the fourth edition of Waterbird Population Estimates (Wetlands International 2006), there are 878 waterbird species (species ecologically dependent on wetlands) in 33 families occurring in 2305 biogeographic populations. The largest number of waterbird populations (815) is found in Asia, followed by the Neotropics (554) and Africa (542). The Pantanal wetland in South America supports 463 bird species in the floodplain habitat alone.

Mammals. Large wetlands can provide refuge for large mammals, many of which are at risk because of their requirement for relatively large tracts of wild land. Overall, however, only about 100 mammal species require wetlands (Lévêque et al. 2005), with common examples including nutria, muskrats, beavers, otters, and hippopotamuses. More than 120 species of mammals occur in the Pantanal and the Okavango Delta (Africa) (Junk et al. 2006). The forest elephant and hippopotamus occur in the wetlands of the Congo River Basin. The Pantanal provides habitat for jaguars, the largest wild cats in the New World. The Sundarbans, part of the Ganges-Brahmaputra River Delta, is said to be the largest piece of estuarine mangrove forest in the world. This area supports the largest remaining population of Bengal tigers. We noted previously the importance of large wetlands for providing habitat for large carnivores in North America, including the Florida panther and Louisiana black bear (figure 2). In many savanna areas, wetlands provide places of refuge for large herds of mammals during periods of drought; including these species would considerably lengthen the list of wetland-dependent mammals.

\section{Four examples: Illustrating large wetland systems}

These four systems are highlighted because they illustrate four important principles that apply to large wetlands elsewhere: the extent of peatlands and their role in carbon storage (the West Siberian Lowland), the role of water-level fluctuations in floodplain wetlands (the Amazon River Basin), the degree of ignorance we still have about large wetlands (the Congo River Basin), and the cumulative effects of human development upon wetlands (the Mississippi River Basin). In addition, these large wetlands illustrate the amount of variation among the world's largest wetlands in terms of wetland type, geographic location, knowledge base, degree of human disturbance, and conservation attention.

\section{The largest peatland: The West Siberian Lowland}

The West Siberian Lowland covers 2,745,000 $\mathrm{km}^{2}$ between the Ural Mountains to the west and the Yenisey River to the east, and the Kara Sea to the north and the Kazakhstan steppes to the south (figures $3,4,5$ ). The northern part of the lowland was subjected to several episodes of glaciation, but whether the area was glaciated during the last glacial maximum is not clear. Permafrost currently covers one-third of the West Siberian Lowland. The continuous permafrost, with a prevailing thickness in the north of more than 500 meters (m), extends southward from the Kara Sea to $64^{\circ} \mathrm{N}$ latitude. The thickness of the permafrost declines southward, and discontinuous permafrost extends to $60^{\circ} \mathrm{N}$ latitude.

The lowland is drained by the two largest North Asian rivers - the $\mathrm{Ob}$ and the Yenisey — and their tributaries. Their freshwater discharges average $402 \mathrm{~km}^{3}$ per year and $577 \mathrm{~km}^{3}$ per year, respectively (Shiklomanov et al. 2000). Because of the flat relief, rivers have not cut deep valleys. The spring flooding begins when snow melts in the south, while the northern stretches of the rivers are still covered by ice. During this period, northern ice dams cause the rivers to flood large areas in the lowland, with an annual difference in amplitude of up to $12 \mathrm{~m}$ between high and low water. Despite the large discharges, Siberian rivers have sediment yields much lower than the world average, and less than those of the Yukon and Mackenzie rivers by about a factor of 10 (Milleman and Meade 1983), possibly because of the low erosion rates, which are attributable to flat topography.

Although the West Siberian Lowland can be classified as a peatland, the distribution of the peat and its depth vary with factors including latitude, elevation, and flood regime. Overall, peatlands cover $787,000 \mathrm{~km}^{2}$ and occupy approximately $30 \%$ of the entire lowland (Ivanov and Novikov 1976). This estimate does not include seasonally flooded riverine forests, wet meadows, and tundra with peat depth less than 40 centimeters. In some regions like Surgutskoye Polesie and Vasjuganye (south taiga) the percentage of peatlands reaches $70 \%$ to $75 \%$. In the taiga zone, where most peatlands occur, the largest peatlands develop on uplands, while the floodplains, because of their better drainage, have mineral soils and are covered by forests and meadows. Peatland formation began in the early Holocene (10,000 to 12,000 years ago) and it continues 


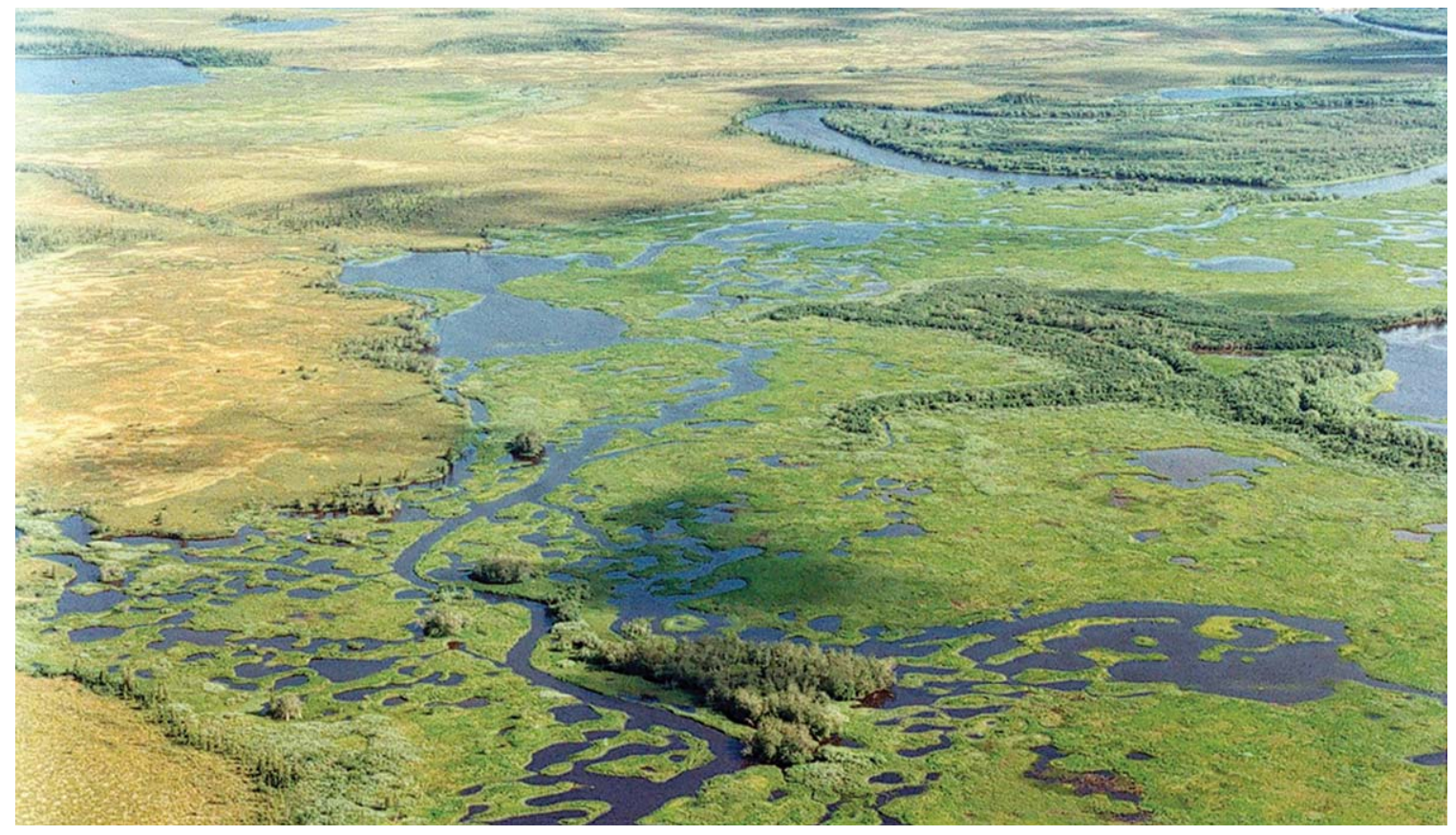

Figure 4. The West Siberian Lowland contains 2.745 million square kilometers dominated by peatlands, such as this floodplain surrounded by tundra. Photograph: Courtesy of Michail Teliatnikov.

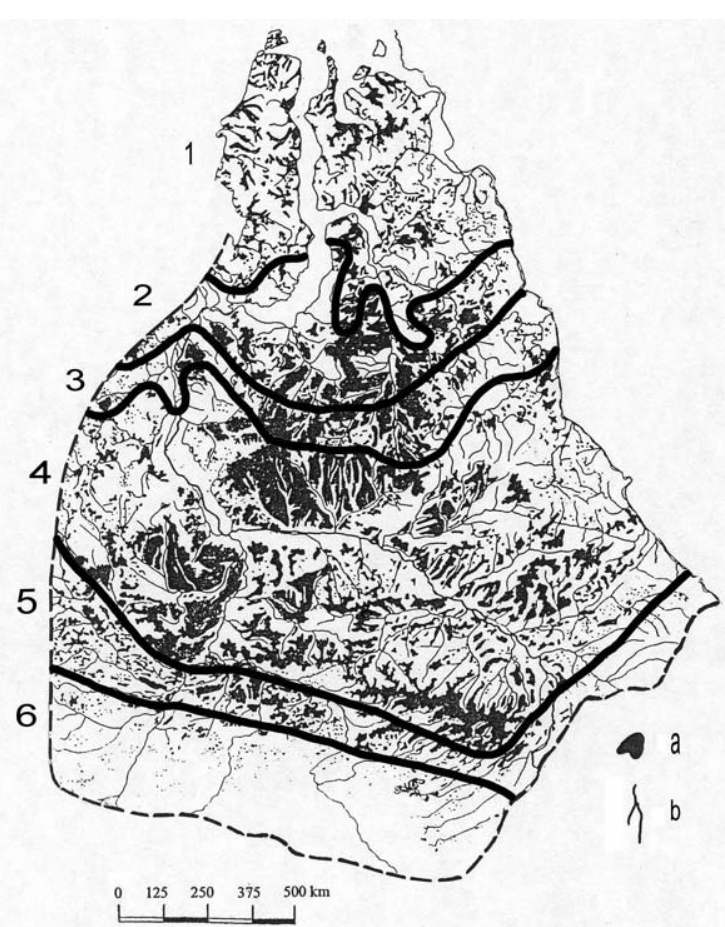

Figure 5. Distribution of wetlands in the West Siberian Lowland. Numbers correspond to mire zones, where 1 = polygonal mires, 2 = flat-palsa mires, 3 = high-palsa mires, $4=$ raised string bogs, $5=$ flat eutrophic and mesotrophic mires, and $6=$ reed and sedge fens and saltwater mashes. (a) Peatlands, (b) rivers (Solomeshch 2005). Reprinted with permission from Cambridge University Press. at present. Initially, peat accumulation started in eutrophic mires, which were gradually transformed into mesotrophic and oligotrophic bogs.

The most common type of peatland is raised string bogs, covering more than half a million $\mathrm{km}^{2}$. Mean peat depths generally range from 2 to $5 \mathrm{~m}$ (up to $11 \mathrm{~m}$ ), averaging $2.4 \mathrm{~m}$. Large bogs have a convex cupola, with a center 3 to $6 \mathrm{~m}$ higher than their margins. The flat central parts of these bogs are treeless, with dystrophic and oligotrophic lakes and wet hollows separated by drier, low peat ridges. One of the largest peatlands in the world is the Vasyugan bog $\left(55^{\circ} 40^{\prime}-57^{\circ} 18^{\prime} \mathrm{N}\right.$; $76^{\circ} 04^{\prime}-82^{\circ} 30^{\prime}$ E) that covers the watershed between the $\mathrm{Ob}$ and Irtysh rivers (Lapshina et al. 2000). It extends $500 \mathrm{~km}$ eastwest and $100 \mathrm{~km}$ north-south, covering an area of $54,000 \mathrm{~km}^{2}$, and contains 14,300 million tons of peat.

In the southern regions of the West Siberian Lowland, in areas typically affected by floodwaters and mineral-rich groundwater, eutrophic marshes become more common and cover some $82,000 \mathrm{~km}^{2}$. These are dominated by large clonal species such as Phragmites australis, Carex vesicaria, Typha latifolia, and Comarum palustre.

\section{The largest floodplain: The Amazon River Basin}

The wetlands of the Amazon River Basin (figures 3, 6) lie within a drainage basin of about $7,000,000 \mathrm{~km}^{2}$ and within a nearly continuous $4,600,000 \mathrm{~km}^{2}$ of lowland humid tropical forest (figure 7; Eva and Huber 1995). The area is drained by a dense network of streams and rivers that are accompanied by fringing floodplains that store and transport part of the large amount of surface runoff during the rainy season. Large interfluvial wetlands are connected by streams to the 
river system. The vegetation composition of the floodplain forests, swamps, and wet savannas is strongly dependent on the duration and amplitude of flooding (figure 8). One of the most striking characteristics of this system is the enormous variation in water levels of the large rivers within a single year-a mean of $11 \mathrm{~m}$ for the Madeira River at Porto Velho, $10 \mathrm{~m}$ for the Amazon River at Manaus, and $6 \mathrm{~m}$ for the Negro River at Barcelos (figure 9). Water-level fluctuations in the interfluvial wetlands reach 1 to $3 \mathrm{~m}$.

The Freshwater Biodiversity Assessment recognizes eight relatively distinct regions in the Amazon complex (excluding the high Andean watershed), and these have been used to devise first and second priority regions for conservation (Olson et al. 2001) The basin can also be subdivided into two ecological categories - uplands built from ancient areas of Brazilian and Guyana Shield and Tertiary and Pleistocene materials of the central basin (terra firme), and floodplains built from recent alluvium. Floodplains can be further categorized according to the amount of sediment and dissolved solids transported by the parent rivers: white-water rivers

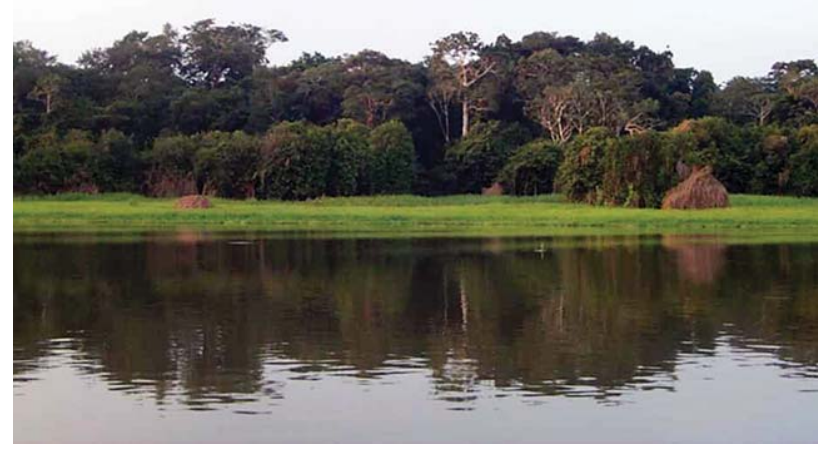

Figure 6. Vast areas of floodplain, both marsh and swamp, occur in the Amazon River Basin. Photograph: Courtesy of Wolfgang J. Junk. carry large sediment loads and electrolytes, drain from the Andes, and form fertile floodplains, locally called várzeas; black-water and clear-water rivers usually drain from tertiary sediments and ancient areas of Brazilian and Guyana Shield, have low suspended and dissolved matter, and form infertile floodplains, locally called igapó (figure 10). Interfluvial wetlands on terra firme are fed by rainwater and are nutrient poor. About $60 \%$ of the entire wetland area is covered with different types of floodplain forest. Open water, savanna, semiaquatic grasslands, and anthropogenic vegetation cover the remaining area. Forest biomass is estimated at 260 tons per ha, $85 \%$ of which is trunks and branches. Owing to the infertile soils, at least in the black-water rivers, these forests capture nutrients from rainfall. Nutrients are then stored in tissue and rapidly recycled from litter-fall by shallow roots and mycorrhizae. The biota is one of the richest on Earth, with more than a thousand species of flood-tolerant trees and several thousand species of fish (Myers et al. 2000, Junk et al. 2006).

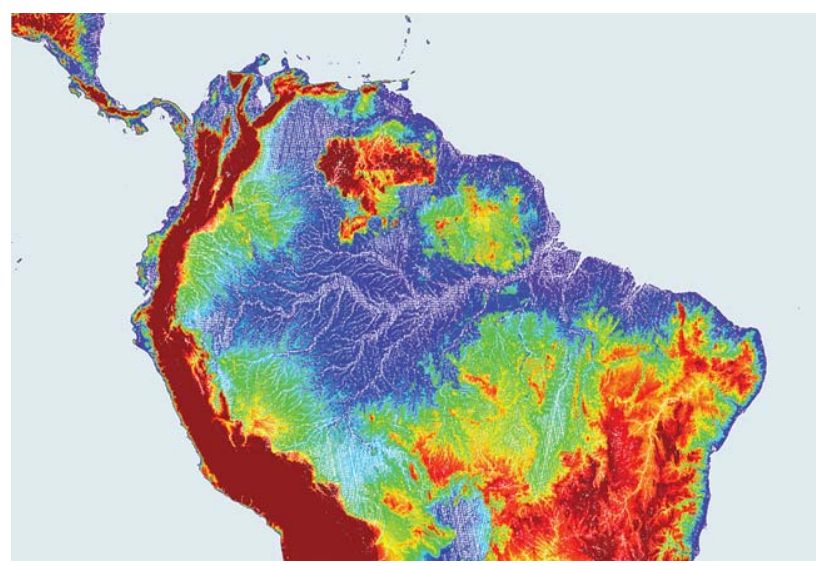

Figure 7. The Amazon River Basin as observed by ERS-1 radar altimeter (European Space Agency, www.esa.int/esaEO/ SEMDHU2VQUD_planet 1.html).

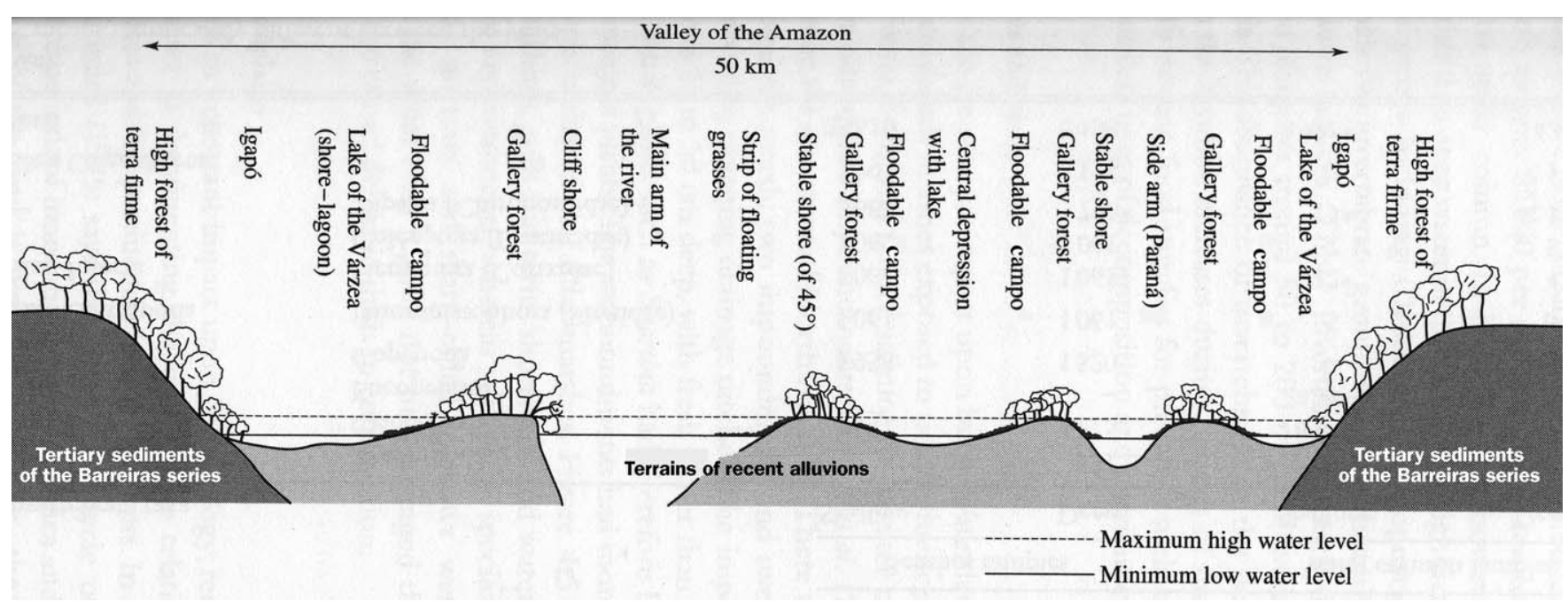

Figure 8. Schematic cross-section of the Amazon floodplain illustrating how water depth and substrate types control the composition of the wetlands and surrounding forests. Source: Sioli (1964). 
a

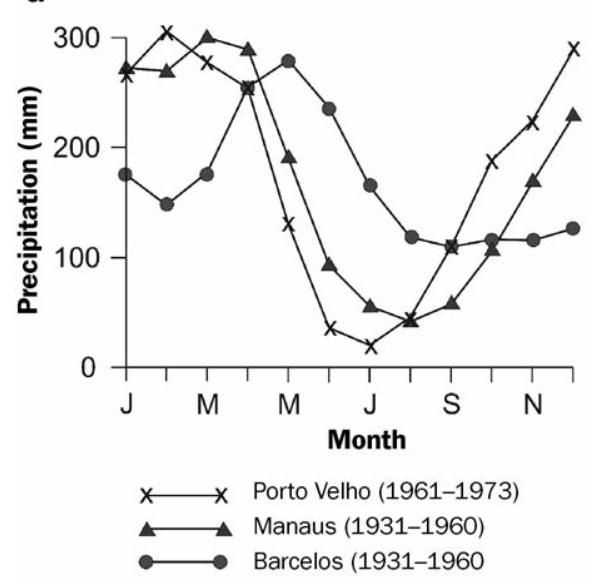

b

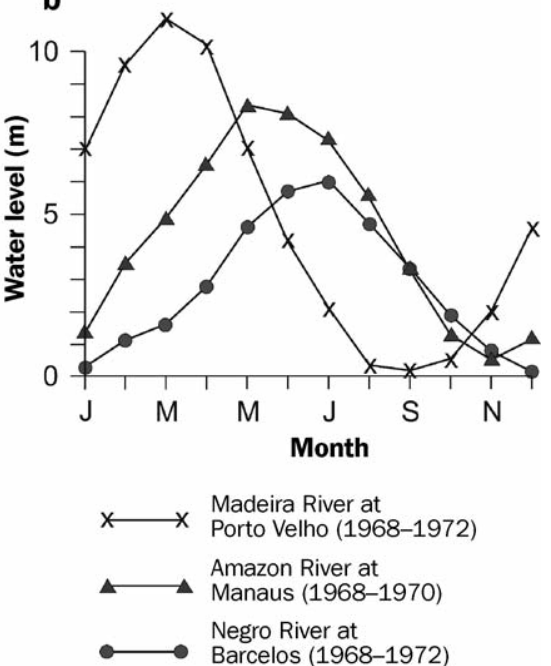

Figure 9. Monthly rainfall in millimeters (a) and water-level fluctuation in meters

(b) in the Madeira River at Porto Velho, the Amazon River at Manaus, and the Negro River at Barcelos, corresponding to the southern, central, and northern parts of the basin (Junk and Piedade 2005). Reprinted with permission from Cambridge

The entire valley of the Amazon River and its large tributaries appears to have been drowned by sea level rise at the beginning of the last warm period about 15,000 BP. During this period, a large dendritic freshwater lake $2500 \mathrm{~km}$ long and up to $100 \mathrm{~km}$ wide may have extended inland from the mouth of the Amazon (Müller et al. 1995). Sediments deposited in this lake would have produced deltas in the middle Amazon. Active erosion and sedimentation still characterize these wetlands-in a 500,000- $\mathrm{km}^{2}$ area of the Peruvian Amazon, $26.6 \%$ of the modern lowland forest shows characteristics of recent erosion and deposition, and fully $12 \%$ of the Peruvian lowland forest is in successional stages along rivers (Salo et al. 1986).

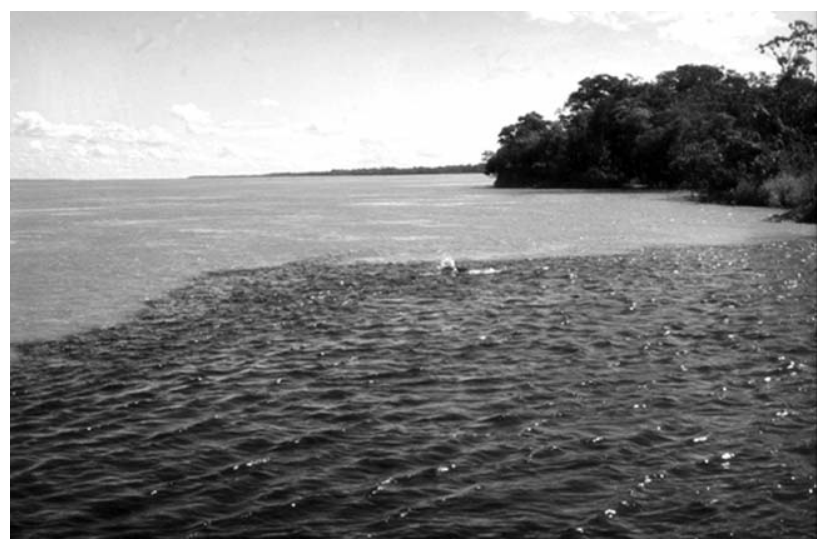

Figure 10. Black water and white water at the confluence of the Negro and Amazon rivers near Manaus (Junk and Piedade 2005). Reprinted with permission from Cambridge University Press. University Press.

\section{The largest unknown: The Congo River Basin}

The Congo River, with a discharge exceeded only by the Amazon, drains 3.7 million $\mathrm{km}^{2}(12 \%)$ of the African continent. From Kisangani to Kinshasa/Brazzaville (figure 11), the river elevation decreases only $115 \mathrm{~m}$ over $1740 \mathrm{~km}$ as it traverses the cuvette centrale congolaise (Hughes and Hughes 1992). Throughout this vast, shallow depression along the equator in the heart of Africa, enormous swamps extend behind the river's levees and along the banks of the numerous tributaries that drain it. This wetland covers about 190,000 km², 69,000 $\mathrm{km}^{2}$ in the Congo and $120,000 \mathrm{~km}^{2}$ in the Democratic Republic of Congo (D. R. Congo, formerly Zaire) (Hughes and Hughes 1992). It is larger than 34 of the 50 states of the United States, or more than four times the size of Switzerland.

The swamps of the Congo are poorly studied and understood, despite their notable size. The majority of the basic research on these swamps dates from colonial times and is buried in obscure publications in France and Belgium (Campbell 2005). They are scarcely referred to in older reviews of African wetland ecology (Thompson and Hamilton 1983,

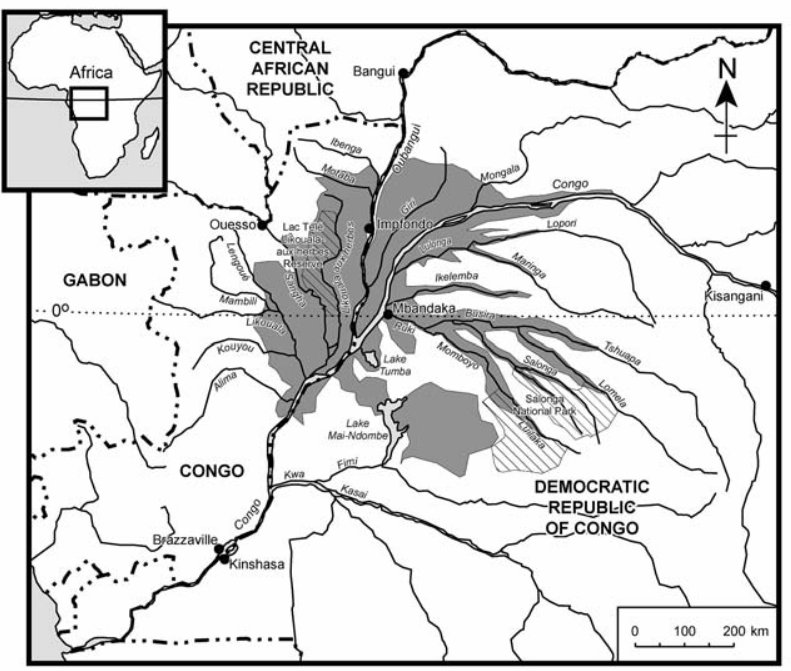

Figure 11. The location of swamps within the cuvette centrale congolaise, based on De Grandi and colleagues (2000). Areas with a mosaic of swamp and terra firme forest are also included. Protected areas are crosshatched. They include the Salonga National Park in the Democratic Republic of Congo, which is one of the largest national parks in the world, and the Lac Télé/Likoualaaux-herbes Community Reserve in the Congo (Campbell 2005). Reprinted with permission from Cambridge University Press. 
Denny 1985). More recently, research largely in the Congo, but also in the D. R. Congo, has focused on tropical rainforests, yet swamps have received little attention.

As with the Amazon, tropical forests of central Africa, including the swamps, have undergone periods of increase and decrease since the mid-Pleistocene epoch (roughly 1.05 million years ago) (Dupont et al. 2001). When central Africa became drier and cooler, during glacial maxima, the tropical forests retreated toward the highlands of eastern and western equatorial Africa. The relatively low proportion of endemic species in the central parts of the Congo River Basin may be a result of such climate changes. The Cameroon highlands to the east and the Albertine Rift highlands to the west (eastern D. R. Congo, Rwanda, Burundi, and Uganda) have been identified as centers of biodiversity (e.g., Linder 2001).

The cuvette centrale congolaise has a complex hydrological system, composed of the Congo River, its many tributaries, and the expansive swamps. The low, gently sloping terrain allows water to flow between watersheds during high water. Within a watercourse, flow can even reverse direction (Laraque et al.2001). River discharge patterns vary within the wetland. Tributaries north of the equator (e.g., Oubangui, Giri) have a single peak in discharge, which occurs in October and November. Others (e.g., Sangha, Likouala) have a second, lower peak flow in May. As a result of discharge patterns from tributaries on both sides of the equator, the Congo River exhibits two notable discharge peaks. Relative to other tropical river systems, such as the Amazon (figure 9), the amplitude of annual water-level fluctuations in the cuvette centrale congolaise is low; for example, the variation in the Congo River at Mbandaka averages only $1.8 \mathrm{~m}$.

Swamp vegetation has been characterized only in a very general manner, with little work done since the 1960s (Campbell 2005). Remote sensing has recently enabled the accurate mapping of regional forest cover, replacing previous maps that just roughly defined swamp extent. Through combinations of satellite imagery, swamp forests have now been identified and, further, periodically flooded and permanently flooded swamps have been distinguished (De Grandi et al. 2000, Mayaux et al. 2002). Although these maps must still be ground-truthed and published, they give a new perspective on the distribution and magnitude of the swamps of the cuvette centrale congolaise.

The history of the Congo River Basin's resources and inhabitants exemplifies the crudest forms of resource exploitation (Hochschild 1998), the results of which contribute to the region's lack of scientific attention. Josef Conrad's 1902 classic book Heart of Darkness was based on a steamboat voyage he made up the Congo River in 1889 at the age of 32. Younger readers may be more familiar with the film Apocalypse Now, which draws heavily upon Heart of Darkness, although moving the location from Africa to Asia. In January 2007, the D. R. Congo's first democratically elected president took power. The future of this great wetland is clearly tied to the future of peace, democracy, and conservation in the countries of West Africa.

\section{The largest developed: The Mississippi River Basin}

Many significant river valleys such as the Nile and Danube once supported extensive wetland systems, but they are now highly disturbed and fragmented through conversion to other land uses, water supply regulation, and water quality decline. Of the largest wetlands (figure 3), those along the Mississippi River (alluvial and deltaic) are probably the most disturbed by humans (figure 12). Not only have vast areas of forest been cleared, but water level regimes have been altered by levees, canals, and massive engineering projects such as the Old River Control structure. Quadrapeds, including bison and panthers, have been extirpated from the basin; the red wolf is extinct in the wild, and the Louisiana black bear is at risk. Carolina parakeets are extinct. Brown pelicans and ospreys, however, are recovering from earlier declines, as are wading birds in general, having been all but extirpated by plume hunters in the late 1800 s.

Modern maps of the Mississippi watershed do not depict the greater area that this river formerly drained. Near the end of the last ice age, for example, the melting ice sheet produced Lake Agassiz. Occasional surges of melt-water poured from this lake down the Mississippi River (Teller 2003). The water came from ice caps, lakes, and rivers that extended far beyond the current drainage basin. In a paleohistorical context, then, even the largest recent floods and delta-building processes are dwarfed by the magnitude of these earlier events. The Mississippi deltaic plain is a composite of seven major deltas that have formed over the last 6000 years, each initiated as the river set a new course. Now, however, levees and the Old River Control Structure have been constructed to confine the Mississippi to one primary channel—-the one passing New Orleans.

The story of resource exploitation in North America has left a watershed that is both largely deforested and heavily controlled by artificial levees (Williams 1989, Barry 1997). If Conrad's Heart of Darkness characterizes the atmosphere of the Congo, then Mark Twain's 1883 Life on the Mississippi similarly might be said to characterize the Mississippi-its steamboats, plantations, expanding artificial levees, and human settlements. In Life on the Mississippi, Twain recounts how there are many points of view on managing the river and its flooding, but all agree on one thing-large amounts of federal money have to be spent.

The extensive system of levees has starved southern swamps of needed nutrients and freshwater, and significantly reduced sediment delivery to coastal marshes (Shaffer et al. 2005, Day et al. 2007, Keddy et al. 2007). Fragmentation of the deltaic wetland by channels cut for cypress logging, navigation, and the oil and gas industry has facilitated saltwater intrusion. Wetland deterioration resulting from these human activities leaves the coast more vulnerable to the effects of hurricanes (Day et al. 2007). There is one large area of relatively intact wetland remaining - the Atchafalaya Swamp (figure 12, lower left) - but even this area is affected by many of the problems described above. Depending on how one draws the boundary 


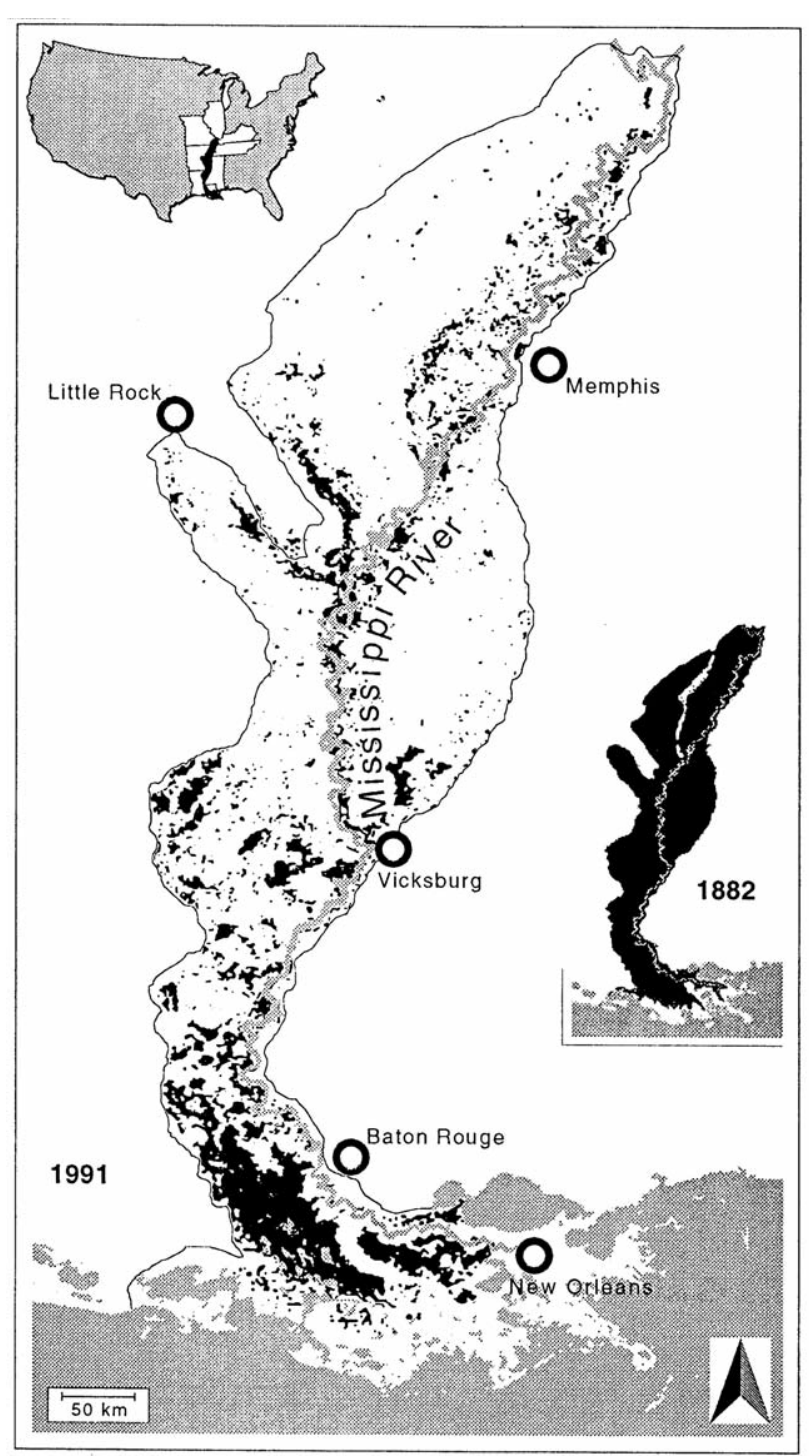

Figure 12. The remaining bottomland hardwood forests of the Mississippi River alluvial plain following extensive logging activities in the river basin since 1882. Source: Llewellyn and colleagues (1996).

around this ecological region, there are at least $4000 \mathrm{~km}^{2}$ still somewhat wet and wild.

Since the state of Louisiana includes nearly all of the Mississippi Delta, restoration will have to focus on the Louisiana coastal zone. It is not yet clear whether the state will be willing to make the decisions necessary to protect the coastal zone, given strong pressures to allow the construction of canals, logging of cypress swamps, and construction of new and larger levees. Louisiana is a test case for how human populations can cope with dynamic deltas, the negative effects of levees, and the prospect of rising sea level.

\section{Recommendations and conclusions}

Unlike biodiversity hotspots (Myers et al. 2000) or frontier forests (Bryant et al. 1997), wetlands have not been accorded a comparable conservation perspective at the global scale until now. These large wetlands constitute their own vital class for conservation planning. We have yet to fully quantify the services performed by large wetlands, but those most important at the global scale may include carbon cycling, freshwater supply, protein production, and maintenance of biodiversity. Beyond this recognition, conservation of the world's largest wetlands requires that both the indirect (population growth, economic exploitation) and direct (e.g., pollution, overfishing, water diversion) drivers of wetland loss and degradation be addressed concurrently.

Each of the world's largest wetlands requires a basinwide sustainable management strategy, built on new institutional frameworks (international, national, and regional), that accurately reflects the inescapable linkages of economy and human well-being to wetland ecosystem sustainability. Strategies must be underlain by a sound resource base derived from standardized, comprehensive, large-scale inventories that quantify and document the distribution of wetland types and assess threats to their services.

There are also considerable — even remarkable—differences in our knowledge base among these wetlands. The wetlands of central Congo are still the most poorly known. The Mississippi River Basin is probably the most intensively studied. Yet the Mississippi River is often treated in isolation, which misses two important scientific opportunities: that of learning from work carried out elsewhere, and that of sharing knowledge. Once basinwide sustainable management strategies are established, it is imperative to encourage the exchange of information among management agencies. Indeed, the challenge of developing common sets of data and common sets of management principles for these large wetlands could unify the study of wetland ecology.

Setting targets for the future of these wetlands will require consideration of trade-offs associated with different scenarios of present and future ecosystem services. This evaluation must incorporate a complete appraisal of subsidies for land uses that contribute to wetland degradation and conversion. Thus decisionmakers must be informed, through documentation and practical experience, about the services provided by wetlands, the impacts of human activities on these services, and the resulting effects on human well-being (MEA 2005).

In an era of rapidly growing human populations, and forecasts of extensive climate change and enormous losses of biodiversity, the wise management of the world's largest wetlands is vital. In coastal wetland areas such as Bangladesh and southern Louisiana, human populations and coastal infrastructure are further threatened by altered hydrology and rising sea level.

Although most of the large wetlands in table 2 exceed $100,000 \mathrm{~km}^{2}$, three are smaller, and it appears that one or more large Asian deltas may qualify for addition to the list. More work is needed at many scales, including delineating large wetland areas, measuring services, and addressing the correspondingly large list of threats. Indeed, the 21 April 2008 issue of Guardian Weekly, under the headline "Banks Meet over $£ 40$ bn Plan to Harness Power of Congo River and Double 
Africa's Electricity," describes how the Grand Inga Dam (150 $\mathrm{m}$ high, twice the power ouput of the Three Gorges Dam on the Yangtze River in China) is proposed for construction 144 $\mathrm{km}$ inland from the river's mouth. Large wetland conservation will certainly continue to be a challenge for the coming generation of wetland ecologists and conservation planners.

\section{Acknowledgments}

We thank Maria Brown and Cathy Keddy for their assistance in preparing the manuscript.

\section{References cited}

Barry JM. 1997. Rising Tide. The Great Mississippi Flood of 1927 and How It Changed America. New York: Simon and Schuster.

Bryant D, Nielsen D, Tangley L. 1997. The Last Frontier Forests: Ecosystems and Economies on the Edge. Washington (DC): World Resources Institute.

Campbell D. 2005. The Congo River Basin. Pages 149-165 in Fraser LH, Keddy PA, eds. The World's Largest Wetlands: Ecology and Conservation. Cambridge (United Kingdom): Cambridge University Press.

Costanza R, et al. 1997. The value of the world's ecosystem services and natural capital. Nature 387: 253-260.

Czaya E. 1983. Rivers of the World. Cambridge (United Kingdom): Cambridge University Press.

Dahl TE. 2000. Status and Trends of Wetlands in the Conterminous United States 1986-1997. Onalaska (WI): US Fish and Wildlife Service.

Day J, et al. 2007. Restoration of the Mississippi Delta: Lessons from hurricanes Katrina and Rita. Science 315: 1679-1684.

De Grandi GF, Mayaux P, Rauste Y, Rosenqvist A, Simard M, Saatchi S. 2000. The Global Rain Forest Mapping Project JERS-1 radar mosaic of tropical Africa: Development and product characterization aspects. IEEE Transactions on Geoscience and Remote Sensing 38: 2218-2233.

de Groot RS. 1992. Functions of Nature. Groningen (Netherlands): WoltersNoordhoff.

Denny P. 1985. The Ecology and Management of African Wetland Vegetation: A Botanical Account of African Swamps and Shallow Waterbodies. Dordrecht (Netherlands): Dr. W. Junk.

deVilliers M. 2003. Water: The Fate of Our Most Precious Resource. Rev. and updated. Toronto: McClelland and Stewart.

Dupont LM, Donner B, Schneider R, Wefer G. 2001. Mid-Pleistocene environmental change in tropical Africa began as early as $1.05 \mathrm{Ma}$. Geology 29: 195-198.

Environment Canada. 2000. The Importance of Nature to Canadians: The Economic Significance of Nature-related Activities. Ottawa (Canada): Environment Canada.

Eva HD, Huber O. 1995. A proposal for defining the geographical boundaries for Amazonia. Luxembourg: Office for Official Publications of the European Communities.

Ewel KC. 1990. Multiple demands on wetlands. BioScience 40: 660-666.

Findlay SC, Houlahan J. 1997. Anthropogenic correlates of species richness in southeastern Ontario wetlands. Conservation Biology 11: 1000-1009.

Finlayson CM, Davidson NC. 1999. Global Review of Wetland Resources and Priorities for Wetland Inventory. Ramsar Bureau Contract 56. Gland (Switzerland): Ramsar Convention Bureau.

Fraser LH, Keddy PA, eds. 2005. The World's Largest Wetlands: Ecology and Conservation. Cambridge (United Kingdom): Cambridge University Press.

Frazier S. 1999. Ramsar Sites Overview: A Synopsis of the World's Wetlands of International Importance. Wageningen (Netherlands): Wetlands International. (27 October 2008; www.wetlands.org/RSIS/Publications/ enovervw.pdf)

Gorham E. 1991. Northern peatlands: Role in the carbon cycle and probable responses to climatic warming. Ecological Applications 1: 182-195.
Hayashi M, van der Kamp G, Schmidt R. 2003. Focused infiltration of snowmelt water in partially frozen soil under small depressions. Journal of Hydrology 270: 214-229.

Hey DL, Philippi NS. 1995. Flood reduction through wetland restoration: The upper Mississippi River Basin as a case study. Restoration Ecology 3: 4-17.

Hochschild A. 1998. King Leopold's Ghost: A Story of Greed, Terror, and Heroism in Colonial Africa. Boston: Houghton Mifflin.

Houlahan J, Keddy P, Makkey K, Findlay CS. 2006. The effects of adjacent land-use on wetland plant species richness and community composition. Wetlands 26: 79-96.

Hughes RH, Hughes JS. 1992. A Directory of African Wetlands. Gland (Switzerland): IUCN (World Conservation Union), UNEP (United Nations Environment Programme), and WCMC (World Conservation Monitoring Centre).

Ivanov KE, Novikov SM. 1976. Bolota Zapadnoi Sibiri, ikh stroenie igidrologicheski rezhim [Bogs of Western Siberia: Their Structure and Hydrological Regime]. Leningrad (Russia): Gidrometeoizdat.

Junk WJ, Piedade MTF. 2005. The Amazon River Basin. Pages 63-117 in Fraser LH, Keddy PA, eds. The World's Largest Wetlands: Ecology and Conservation. Cambridge (United Kingdom): Cambridge University Press.

Junk WJ, Brown M, Campbell IC, Finlayson M, Gopal B, Ramberg L, Warner BG. 2006. The comparative biodiversity of seven globally important wetlands: A synthesis. Aquatic Sciences 68: 400-414.

Kadlec RH, Knight RL. 1996. Treatment Wetlands. New York: Lewis.

Keddy PA. 2000. Wetland Ecology: Principles and Conservation. Cambridge (United Kingdom): Cambridge University Press.

Keddy PA, Fraser LH. 2005. Introduction: Big is beautiful. Pages 1-10 in Fraser LH, Keddy PA, eds. The World's Largest Wetlands: Ecology and Conservation. Cambridge (United Kingdom): Cambridge University Press.

Keddy PA, Campbell D, McFalls T, Shaffer G, Moreau R, Dranguet C, Heleniak R. 2007. The wetlands of lakes Pontchartrain and Maurepas: Past, present and future. Environmental Reviews 15: 1-35.

Khramov AA, Valutsky VI. 1977. Lesnye i bolotnye fitotsenozy vostochnogo Vasiugania [Forest and mire phytocoenosises of eastern Vasiuganie]. Novosibirsk (Russia): Nauka.

Kremenetski KV, Velichko AA, Borisova OK, MacDonald G, Smith LC, Frey KE, Orlova LA. 2003. Peatlands of the Western Siberian Lowland: Current knowledge on zonation, carbon content and late Quaternary history. Quaternary Science Review 22: 703-723.

Lapshina ED, Korolyuk A, Bleuten W, Muldiyarov EY, Valutsky VI. 2000. Struktura rastitel'nogo pokrova zapadnoy chasti Bol'shogo Vasyuganskogo bolota na primere klyuchevogo uchastka "Uzas" [Structure of the vegetation of the western part of the Great Vasyugan Bog: Example from the key area "Uzas"]. Sibirsky Ecologichesky Zhurnal 7: 563-576.

Laraque A, Mahé G, Orange D, Marieu B. 2001. Spatiotemporal variations in hydrological regimes within Central Africa during the XXth century. Journal of Hydrology 245: 104-117.

Lévêque C, Balian EV, Martens K. 2005. An assessment of animal species diversity in continental waters. Hydrobiologia 542: 39-67.

Linder HP. 2001. Plant diversity and endemism in sub-Saharan tropical Africa. Journal of Biogeography 28: 169-182.

Llewellyn DW, Shaffer GP, Craig NJ, Creasman L, Pashley D, Swan M, Brown C. 1996. A decision-support system for prioritizing restoration sites on the Mississippi River alluvial plain. Conservation Biology 10: 1446-1455.

Lowe-McConnell RH. 1975. Fish Communities in Tropical Freshwaters: Their Distribution, Ecology and Evolution. London: Longman.

Mayaux P, De Grandi GF, Rauste Y, Simard M, Saatchi S. 2002. Large-scale vegetation maps derived from the combined L-band GRFM and C-band CAMP wide area radar mosaics of Central Africa. International Journal of Remote Sensing 23: 1261-1282.

[MEA] Millenium Ecosystem Assessment. 2005. Ecosystems and Human Well-being: Wetlands and Water Synthesis. Washington (DC): World Resources Institute.

Meyer JL, Kaplan LA, Newbold D, Strayer DL, Woltermade CJ, Zedler JB. 2003. Where Rivers Are Born: The Scientific Imperative for Protecting Small Streams and Wetlands. Washington (DC): American Rivers and Sierra Club. (28 October 2008; www.sierraclub.org/healthycommunities/rivers/ WRABreport_full.pdf) 
Milleman JD, Meade RH. 1983. World-wide delivery of river sediment to the oceans. Journal of Geology 91: 1-21.

Mirza MMQ. 2003. Three recent extreme floods in Bangladesh: A hydrometerological analysis. Natural Hazards 28: 35-64.

Mitra S, Wassmann R, Vlek LG. 2005. An appraisal of global wetland area and its organic carbon stock. Current Science 88: 25-35.

Mitsch WJ, Gosselink JG. 2000. Wetlands. 3rd ed. New York: Wiley.

Mitsch WJ, Day JW Jr, Gilliam JW, Groffman PM, Hey DL, Randall GW, Wang N. 2001. Reducing nitrogen loading to the Gulf of Mexico from the Mississippi River Basin: Strategies to counter a persistent ecological problem. BioScience 51:373-388.

Moser M, Prentice C, Prazier S. 1996. A Global Overview of Wetland Loss and Degradation. Proceedings of the 6th Meeting of the Conference of Contracting Parties of the Ramsar Convention, vol. 10. (28 October 2008; www.ramsar.org/about/about_wetland_loss.htm)

Müller J, Irion G, de Mello JN, Junk WJ. 1995. Hydrological changes of the Amazon during the last glacial-interglacial cycle in central Amazonia (Brazil). Naturwissenschaften 82: 232-235.

Myers N, Mittermeier RA, Mittermeier CG, da Fonseca GAB, Kent J. 2000. Biodiversity hotspots for conservation priorities. Nature 403: 853-858.

[NRC] National Research Council. 2001. Compensating for Wetland Losses under the Clean Water Act. Washington (DC): National Academy of Sciences.

Olson DM, et al. 2001. Terrestrial ecoregions of the world: A new map of life on Earth. BioScience 51: 933-938.

Postel SL, Daily GC, Ehrlich PR. 1996. Human appropriation of renewable fresh water. Science 271: 785-788.

Richey JE, Hedges JI, Devol AH, Quay PD. 1990. Biogeochemistry of carbon in the Amazon River. Limnology and Oceanography 35: 352-371.

Roulet NT. 2000. Peatlands, carbon storage, greenhouse gases, and the Kyoto Protocol: Prospects and significance for Canada. Wetlands 20: 605-615.

Salo J, Kalliola R, Hakkinen I, Makinen Y, Niemela P, Puhakka M, Coley PD. 1986. River dynamics and the diversity of Amazon lowland forest. Nature 322: 254-258.

Shaffer GP, Gosselink JG, Hoeppner SS. 2005. The Mississippi River alluvial plain. Pages 272-315 in Fraser LH, Keddy PA, eds. The World's Largest Wetlands: Ecology and Conservation. Cambridge (United Kingdom): Cambridge University Press.

Shiklomanov IA, Shiklomanov AI, Lammers RB, Peterson BJ, Vorosmarty CJ. 2000. The dynamics of river water inflow to the Arctic Ocean. Pages 281-296 in Lewis LE, Jones EP, Lemke P, Prowse TD, Wadhams P, eds. The Freshwater Budget of the Arctic Ocean. New York: Kluwer .

Sioli H. 1964. General features of the limnology of Amazonia. Verhandlungen/Internationale Vereinigung für theoretische and angewandte Limnologie 15: 1053-1058.

Solomeshch AI. 2005. The West Siberian Lowland. Pages 11-62 in Fraser LH, Keddy PA, eds. The World's Largest Wetlands: Ecology and Conservation. Cambridge (United Kingdom): Cambridge University Press.

Spiers AG. 2001. Wetland inventory: Overview at a global scale. Pages 23-30 in Finlayson CM, Davidson NC, Stevenson NJ, eds. Wetland Inventory, Assessment and Monitoring: Practical Techniques and Identification of Major Issues. Proceedings of Workshop 4, 2nd International Conference on Wetlands and Development, Dakar, Senegal, 8-14 November 1998. Darwin (Australia): Department of the Environment and Water Resources. Supervising Scientist Report 161.

Teller JT. 2003. Controls, history, outbursts and impact of large late-Quaternary proglacial lakes in North America. Pages 45-61 in Gillespie AR, Porter SC, Awater BF, eds. The Quaternary Period in the United States. Amsterdam: Elsevier.

Tharme RE. 2003. A global perspective on environmental flow assessment: Emerging trends in the development and application of environmental flow methodologies for rivers. River Research and Applications 19: 1-45.

Thompson K, Hamilton AC. 1983. Peatlands and swamps of the African continent. Pages 331-373 in Gore AJP, ed. Ecosystems of the World, vol. 48: Mires: Swamp, Bog, Fen and Moor. Amsterdam: Elsevier.

Tiner RW. 2005. Assessing cumulative loss of wetland functions in the Nanticoke River watershed using enhanced national wetland inventory data. Wetlands 25: 405-419.

Turner RE. 1977. Intertidal vegetation and commercial yields of penaeid shrimp. Transactions of the American Fisheries Society 106: 411-416.

Turner RE, Redmond A, Zedler JB. 2001. Count it up by acre or function: Mitigation adds up to net loss of wetlands. National Wetlands Newsletter 23: 5-16.

Turunen J, Tomppo E, Tolonen K, Reinikainen A. 2002. Estimating carbon accumulation rates of undrained mires in Finland: Application to boreal and subarctic regions. The Holocene 12: 69-80.

Walter BP, Heimann M, Matthews E. 2001. Modeling modern methane emissions from natural wetlands, 1: Model description and results. Journal of Geophysical Research 106: 34,189-34,206.

Welcomme RL. 1976. Some general and theoretical considerations on the fish yield of African rivers. Journal of Fish Biology 8: 351-364.

Wetlands International. 2006. Waterbird Population Estimates. 4th ed. Wageningen (Netherlands): Wetlands International.

Williams M. 1989. The lumberman's assault on the southern forest, 1880-1920. Pages 238-288 in Williams M, ed. Americans and Their Forests: A Historical Geography. Cambridge (United Kingdom): Cambridge University Press.

Paul A. Keddy (e-mail: drpaulkeddy@gmail.com) is the first holder of the Edward G. Schlieder Endowed Chair for Environmental Studies in the Department of Biological Sciences at Southeastern Louisiana University in Hammond, Louisiana. Lauchlan H. Fraser holds a Canada Research Chair in Community and Ecosystem Ecology at Thompson Rivers University in Kamloops, British Columbia, Canada. Ayzik I. Solomeshch is a project scientist at the Department of Plant Sciences, University of California, Davis. Wolfgang J. Junk is a professor at Max-Planck-Institute for Evolutionary Biology, Tropical Ecology Working Group, in Plön, Germany. Daniel R. Campbell is a professor at Laurentian University in Sudbury, Ontario, Canada. Mary T. K. Arroyo is a professor at the Institute of Ecology and Biodiversity at the University of Chile in Santiago. Cleber J. $R$. Alho is a professor at the Universidade para o Desenvolvimento do Estado e da Região do Pantanal in Brazil. 


\section{ZOOLOGY \& ORNITHOLOGY}

\section{SPECIMEN CABINETS}

\section{PERMANENT SPECIMEN PRESERVATION}

For over forty years, Lane Science Equipment has been the name museums, universities and individual collectors trust most to protect their valuable specimens.

To learn more about our Zoology \& Ornithology Cabinets or any of our other products, visit our website at www.lanescience.com or contact us at the listing below.

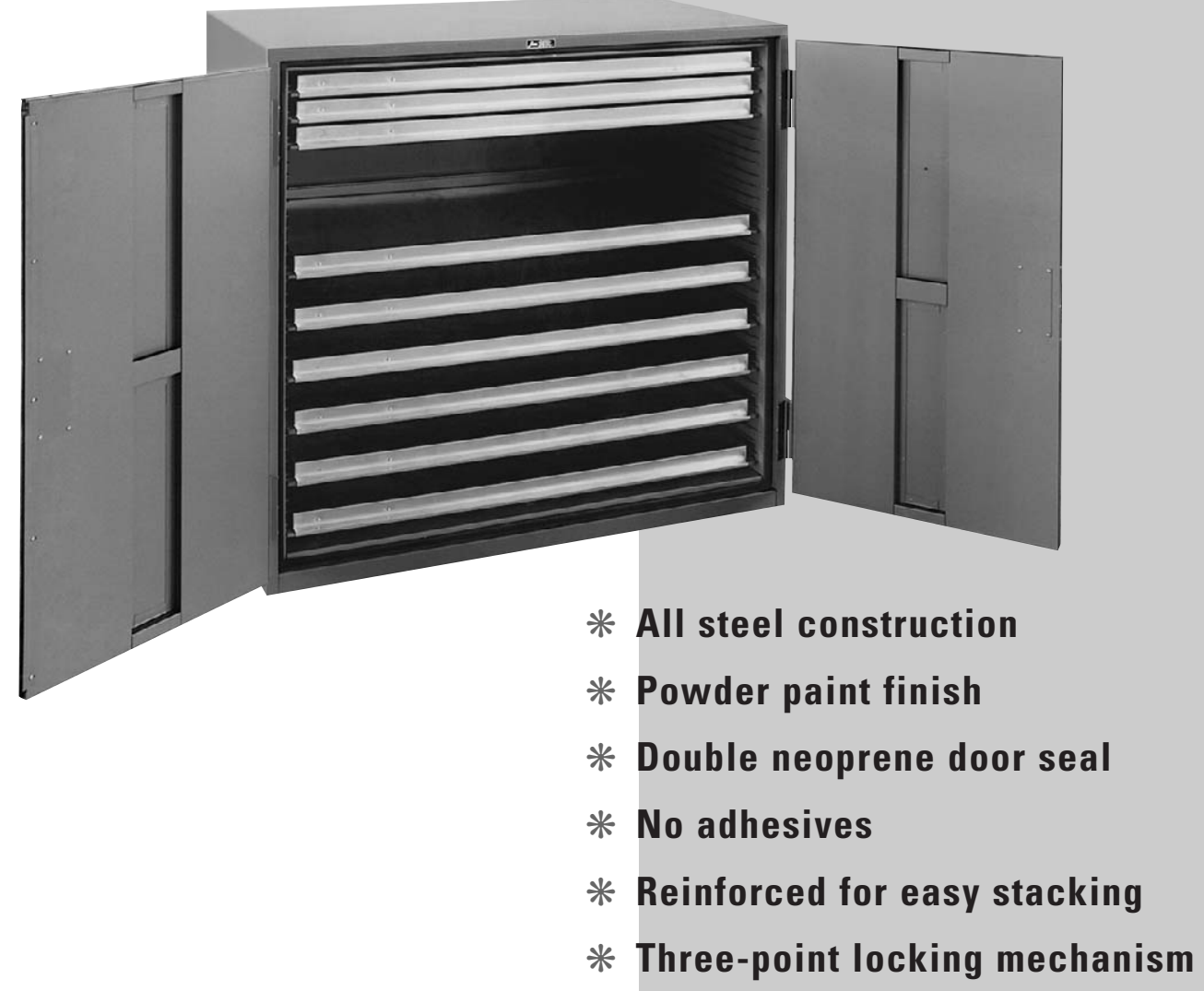

225 West 34th Street Suite 1412 New York, NY 10122-1496
Tel: 212-563-0663 Fax: $212-465-9440$ www.lanescience.com 